\title{
Evaluation of the Use of Sodium Thiocyanate and Sodium Percarbonate in the Activation of the Lactoperoxidase System in the Conservation of Raw Milk without Refrigeration in the Ecuadorian Tropics
}

\author{
Martin Campos-Vallejo1,2, Byron Puga-Torres ${ }^{3}$, Luis Núñez-Naranjo ${ }^{3,4}$, \\ David De la Torre-Duque ${ }^{3,4}$, Samantha Morales-Arciniega ${ }^{3}$, Enrique Vayas ${ }^{2}$ \\ ${ }^{1}$ Carchi Polytechnic University, Tulcán, Ecuador \\ ${ }^{2}$ School of Engineering of Livestock Industries, Chimborazo Polytechnic School, Riobamba, Ecuador \\ ${ }^{3}$ School of Veterinary Medicine and Animal Science, Central University of Ecuador, Quito, Ecuador \\ ${ }^{4}$ Department of Experimental and Comparative Pathology, School of Veterinary Medicine and Animal Science, University of São \\ Paulo, São Paulo, Brazil \\ Email: *bpuga@uce.edu.ec
}

How to cite this paper: Campos-Vallejo, M., Puga-Torres, B., Núñez-Naranjo, L., De la Torre-Duque, D., Morales-Arciniega, S. and Vayas, E. (2017) Evaluation of the Use of Sodium Thiocyanate and Sodium Percarbonate in the Activation of the Lactoperoxidase System in the Conservation of Raw Milk without Refrigeration in the Ecuadorian Tropics. Food and Nutrition Sciences, 8, 526-534.

https://doi.org/10.4236/fns.2017.85036

Received: April 21, 2017

Accepted: May 15, 2017

Published: May 18, 2017

Copyright (c) 2017 by authors and Scientific Research Publishing Inc. This work is licensed under the Creative Commons Attribution International License (CC BY 4.0).

http://creativecommons.org/licenses/by/4.0/ (c) (i) Open Access

\begin{abstract}
Milk production in Ecuador has enormous economic importance and large-, medium- and small-scale producers all participate in the market. There are multiple climatic regions, and dairy production is present in every one of them. High ambient temperatures in the Ecuadorian tropics represent a key challenge to the conservation of milk in the custody of smallholders. The objective of the present study was to evaluate the efficiency of the application of a chemical activator of the Lactoperoxidase System (LP-s) in the conservation of raw milk, at room temperature, in the Ecuadorian tropics. In the present study, sodium thiocyanate- $0.36 \mathrm{~g} \cdot \mathrm{L}^{-1}$ of milk-and sodium percarbonate $-1.36 \mathrm{~g} \cdot \mathrm{L}^{-1}$ of milk-as an activator of LP-s were used and the $\mathrm{pH}$ and microbiological characteristics (total coliforms, Staphylococcus aureus, total aerobes, molds and yeasts) of the milk at different storage times (0,4 and 8 hours). The results obtained in the present study showed a significant difference between the two groups under study at 8 hours of storage at room temperature in all parameters (except yeasts where there was no growth in the two treatments), being relevant the significant decrease of the bacterial content. Thus the present study shows that the use of sodium thiocyanate and sodium percarbonate in the above described concentrations could be modulating the activation of LP-s that provides an efficient alternative for the conservation of the raw milk without refrigeration, improving the income for losses of the
\end{abstract}


product and obtaining a raw material of good quality for sale or for further processing, mainly for small producers who do not have the economic resources to have refrigeration means for their product and who must transport their milk for considerably longer distances until they arrive at the collection centers or the processing plants for sale, thus showing that the method used in the present study is not only effective but also has a relatively low cost and easy application.

\section{Keywords}

Lactoperoxidase System, Raw Milk, Conservation, Coliforms

\section{Introduction}

Milk is secreted from the mammary gland of female bovines and constitutes the only nutrition for mammals in the first days of their lives; it is capable of providing energy and nutrients necessary for neonatal development [1]. These nutrients constitute an ideal culture medium for contamination by, and subsequent growth of, bacteria. The resulting decomposition easily converts contaminated milk into a foodstuff that is apt for neither human consumption nor use in manufacturing derivatives [2]. This occurs because milk is secreted from the udder at a temperature of $37^{\circ} \mathrm{C}$-ideal for bacterial growth. Even if bacteria are not present in it initially, milk becomes quickly contaminated by microorganisms in the nearby environment. Notwithstanding precautions taken in the milking process, in the absence of a direct response to contamination, these microorganisms develop and reproduce with ease [1]. Raw milk is defined as milk that has not been submitted to any type of heat and whose temperature has not exceeded $40^{\circ} \mathrm{C}[3]$.

In Ecuador, according to reports by the Ministry of Agriculture (MAGAP), 75 percent of milk production is realized in small and medium scale farms (between one and 100 hectares). The majority of these production units do not enjoy ideal conditions for refrigeration and cold-chain storage, for which quality inevitably suffers, and this in turn goes hand-in-hand with product rejections by processing plants or distributors [4].

Members of the mammalian enzyme family heme peroxidase can detoxify peroxide, afford protection against pathogenic microorganisms and even induce hormone production in the thyroid gland [5]. Lactoperoxidase (LA) is a natural enzyme found in raw milk [2] considered a glycoprotein that contains calcium and iron available in a single polypeptide chain spanning approximately $80 \mathrm{kDa}$ [5] which belongs to the superfamily hemoperoxidase of mammals whose other members include myeloperoxidase (MPO), eosinophil peroxidase (EPO) and thyroid peroxidase (TPO); it possesses a hemo-group attached to a protein via two or three covalent bonds [6]; it is considered a milk hemoprotein whose function is to act as a protector protein (although it is not considered an immu- 
noglobulin) due to its strong antimicrobial activity [7]. LA, in the presence of hydrogen peroxide or sodium percarbonate, catalyzes the reaction of sulfocyanide (also naturally found in milk), which has a bacteriostatic over the majority of bacteria, and even a bactericidal effect in some cases [2], as was confirmed in three strains of Escherichia coli K12 [8], and even with antiviral activities [7]. The sulfocyanide ion is a natural component in bovine milk, and whose levels can be artificially increased in order to activate the LP-s of milk preservation. The median concentration varies between 20 and $30 \mathrm{mg} / \mathrm{kg}$, rendering it innocuous [5] [9]. In Latin America, there have been laboratory studies and field tests of the activation of the LP-system (lactoperoxidase-thiocyanate-peroxide of hydrogren) in order to preserve milk through the reduction of the bacterial load and consequently avoid its decomposition and subsequent rejection [10]. Since 2005 , this system has been recognized and endorsed by the FAO and WTO, with the scientific backing of Codex Alimentarius [2].

The objective of this study is to evaluate the efficacy of the application of sodium thiocyanate and sodium percarbonate in the milk as an activator of the Lactoperoxidase system (LP-s) for the conservation of raw milk, at ambient temperature, in the Ecuadorian tropics, because is not considered adulterant of the milk, nor is it detected in the quality-control tests for itself [10] [11] [12] aside from being a mechanism approved by the World Health Organization [2]; too is very important to known an effective and economical alternative in service of the conservation of raw milk in the Ecuadorian tropics, among other locations where the conditions do not permit the use of the refrigeration as a method of conservation of the milk, because it requires higher capital expenditure as well as elevated operational costs, just as much as in locations in where the extant production of milk is extensive, with the goal of augmenting smallholder participation in the production, elaboration and commercialization of dairy products, upon reducing losses by utilizing the LP-s method.

\section{Methodology}

This study was carried out in the dairy manufacturing plant of the experimental farm "La María" of the Universidad Técnica Estatal de Quevedo $(240 \mathrm{~km}$ southwest of Quito), located in the coastal region of Ecuador, in the province of Los Ríos, a median altitude of 74 mamsl, with temperature oscillating between 20 and $35^{\circ} \mathrm{C}$, and annual precipitation of $2461 \mathrm{~cm}^{3}$.

\subsection{Study Design}

The study comprised 4 consecutive trials, which consisted of experimental analysis of the $\mathrm{pH}$ and microbiology of raw milk at distinct intervals of verification $\left(0,4\right.$, and 8 hours) at the same temperature (ambient between $20^{\circ} \mathrm{C}$ and $35^{\circ} \mathrm{C}$ ). 24 experimental units were utilized, each consisting of one liter of milk collected in sterile plastic container according to the recommendations established in NTE INEN 4 [13]. The milk was collected directly from a common drum of milk that had been freshly extracted from apparently healthy animals of the experi- 
mental farm of the university. Of the 24 experimental units, 12 received the activator of the LP-s and the following 12 did not receive the activator. These were subsequently monitored in the times and temperatures indicated above; 4 repetitions were realized (Table 1). The activator of the LP-s was formed from the following compounds: sodium thiocyanate $(0.36 \mathrm{~g})$ and sodium percarbonate (1.36 g) per liter of milk. Two conditions of conservation of the milk were observed: raw milk (Control-T0) and raw milk incorporated the activator of the LP-s (Treatment $1-\mathrm{T} 1$ ), the same that was analyzed under a completely randomized design.

After monitoring at the 0-, 4- and 8-hour intervals, samples were taken to realize the laboratory analyses, in order to determine $\mathrm{pH}$ and bacterial levels. The tests were performed in the Laboratory of Bromatology and in the Laboratory of Microbiology of the Department of Animal Sciences Engineering at the Universidad Estatal de Quevedo. The $\mathrm{pH}$ was determined through the use of $\mathrm{pH}$ meter; the count of total coliforms in accordance with the instructions of the technical documentation of Petrifilm CC plates, and the reading according the AOAC, Official Methods SM 986.33, 989.10 and 991.14; the total aerobes based on the technical documentation of Petrifilm 3M plates; Staphylococcus aureus according to the instructions in the technical documentation of Petrifilm $3 \mathrm{M}$ plates, and the incubation in accordance with the AOAC Official Methods 2003.08 for counts in dairy products; mold and yeast by way of Petrifilm 3M plates, and the incubation according to the AOAC Official Methods SM 997.02 for foodstuffs.

Milk density was measured according to the established protocols in NTE 11:84, via of the method of the thermo lacto densimeter. The measurement of fat content was realized based on the Gerber Method, specifically as detailed in NTE INEN 12:73.

\subsection{Statistical Analysis}

In order to development the statistical analysis and determine if there was a statistically significant difference between the treatments, ANOVA was used for the

Table 1. Treatment and control arms.

\begin{tabular}{|c|c|c|c|c|c|c|}
\hline \multirow{2}{*}{\multicolumn{2}{|c|}{ TREATMENT }} & \multirow{2}{*}{$\begin{array}{l}\text { EVALUATION } \\
\text { TIME }\end{array}$} & \multirow{2}{*}{ CODE } & \multirow{2}{*}{$\begin{array}{c}\# \\
\text { REP }\end{array}$} & \multirow{2}{*}{$\frac{\text { EU/ }}{\text { Liters }}$} & \multirow{2}{*}{$\begin{array}{c}\text { EU/ } \\
\text { TREAT }\end{array}$} \\
\hline & & & & & & \\
\hline & & 0 hours & $\mathrm{C} 0$ & 4 & 1 & 4 \\
\hline \multirow[t]{2}{*}{ Control (T0) } & Raw milk & 4 hours & $\mathrm{C} 4$ & 4 & 1 & 4 \\
\hline & & 8 hours & C 8 & 4 & 1 & 4 \\
\hline Treatment 1 & & 0 hours & T1 0 & 4 & 1 & 4 \\
\hline \multirow[t]{3}{*}{ (T1) } & $\begin{array}{c}\text { Raw milk + } \\
\text { activator LP-s }\end{array}$ & 4 hours & T1 4 & 4 & 1 & 4 \\
\hline & & 8 hours & T1 8 & 4 & 1 & 4 \\
\hline & & TOTAL: & & & & 24 \\
\hline
\end{tabular}

EU: Experimental unit. TREAT: Treatment. REP: Repetitions. LP-s: Lactoperoxidase system. 
differences in $\mathrm{pH}$ and the difference in medians applying a Waller-Duncan test with a significance level of $\alpha \leq 0.05$ and Rating test for non-parametric variables.

\section{Results}

The results with respect to the physio-chemical characteristics showed marked differences in $\mathrm{pH}$ that are significant at the 5 percent level according to the Waller-Duncan test (Table 2). The $\mathrm{pH}$ normal of the milk oscillates between $6.6 \mathrm{a}$ 6.8 , varying as a function of the method of conservation and the time of storage. The milk without the activator of the LP-s registered a pH of: $6.71,6.4$ and 6.13 a the 0,4 and 8 hours of storage respectively, while with the addition of the activator of the LP-s the $\mathrm{pH}$ maintained values of $6.74,6.73$, and 6.68, a the 0,4 and 8 hours of storage respectively; these values show that the use of the activator of the LP-s maintained a stable $\mathrm{pH}$ in the treated milk, compared to the milk without the activator.

With respect to the microbiological characteristics in this study, the total coliform presence was elevated in milk without the added activator of the LP system; values of $100.5,338.75$ and $477.25 \times 10^{3} \mathrm{CFU} / \mathrm{cm}^{3}$ were registered at 0,4 and 8 hours of storage, respectively. Meanwhile, with the addition of the LP-s, coliforms reached values of $51.25,123$ and $295.50 \times 10^{3} \mathrm{CFU} / \mathrm{cm}^{3}$ at 0,4 and 8 hours of storage, respectively (Table 2). The presence of Staphylococcus aureus was higher in milk without the addition of the activator of the LP-s, reaching values of $31.50,102.25$ and $160.25 \mathrm{CFU} / \mathrm{cm}^{3}$ at the 0,4 and 8 hours of storage. With the addition of the LP-s activator, the presence of Staphylococcus aureus showed values of $19.50,14$ and $58.75 \mathrm{CFU} / \mathrm{cm}^{3}$ at the 0 -, 4 - and 8-hour intervals of storage, respectively (Table 2 ). Total aerobic presence was elevated in the milk

Table 2. Results of the study with respect to $\mathrm{pH}$ and microbiological tests of milk submitted to the action of the LP-s in interaction with the different times of storage.

\begin{tabular}{|c|c|c|c|c|c|c|c|c|c|c|c|c|c|}
\hline \multirow{3}{*}{$\begin{array}{c}\text { Variables } \\
\mathrm{pH}\end{array}$} & \multicolumn{12}{|c|}{ Treatments by hours of application } & \multirow{3}{*}{$\begin{array}{l}\text { sign } \\
* *\end{array}$} \\
\hline & \multicolumn{2}{|c|}{ TOHO } & \multicolumn{2}{|c|}{ T0H4 } & \multicolumn{2}{|c|}{ T0H8 } & \multicolumn{2}{|c|}{$\mathrm{T} 1 \mathrm{H} 0$} & \multicolumn{2}{|c|}{$\mathrm{T} 1 \mathrm{H} 4$} & \multicolumn{2}{|c|}{$\mathrm{T} 1 \mathrm{H} 8$} & \\
\hline & 6.71 & $\mathrm{~A}$ & 6.40 & $\mathrm{~b}$ & 6.13 & c & 6.74 & A & 6.73 & $\mathrm{a}$ & 6.68 & a & \\
\hline $\begin{array}{c}\text { Total } \\
\text { coliforms } \\
\mathrm{CFU} / \mathrm{cm}^{3}\end{array}$ & 100.5 & $\mathrm{~cd}$ & 338.75 & $a b$ & 477.25 & $\mathrm{a}$ & 51.25 & $\mathrm{D}$ & 123.0 & bcd & 295.5 & $a b c$ & ** \\
\hline $\begin{array}{c}S \text { aureus } \\
\mathrm{CFU} / \mathrm{cm}^{3}\end{array}$ & 31.50 & $\mathrm{bc}$ & 102.25 & $\mathrm{ab}$ & 160.25 & $\mathrm{a}$ & 19.50 & bc & 14.00 & c & 58.75 & $\mathrm{bc}$ & $* *$ \\
\hline $\begin{array}{c}\text { Total } \\
\text { aerobes } \\
\mathrm{CFU} / \mathrm{cm}^{3}\end{array}$ & 243.75 & $\mathrm{~B}$ & 434.75 & $a b$ & 618.25 & a & 209.5 & B & 308.3 & $\mathrm{~b}$ & 418.5 & $a b$ & $* *$ \\
\hline $\begin{array}{c}\text { Mold } \\
\mathrm{CFU} / \mathrm{cm}^{3}\end{array}$ & 12.75 & $\mathrm{bc}$ & 14.25 & bc & 28.50 & $\mathrm{a}$ & 9.50 & $\mathrm{C}$ & 10.25 & bc & 18.00 & $a b$ & $* *$ \\
\hline $\begin{array}{c}\text { Yeasts } \\
\mathrm{CFU} / \mathrm{cm}^{3}\end{array}$ & 0.00 & A & 0.00 & $\mathrm{a}$ & 0.00 & a & 0.00 & A & 0.00 & $\mathrm{a}$ & 0.00 & $\mathrm{a}$ & ns \\
\hline
\end{tabular}

Similar key do not differ significantly according to the Waller Duncan al 5\%. T0: Control treatment. ns: No significant difference. ${ }^{* *}$ : Difference highly significant. sig: Significance. CFU: Colony Forming Units. 
without the addition of the activator of the LP-s, as seen in the values of 243.75 , 434.75 and $618.250 \mathrm{CFU} / \mathrm{cm}^{3}$ respectively registered at the $0-$, 4 - and 8-hour storage intervals, while with the addition of the activator of the LP-s the presence of total aerobes reached values of $209.50,308.25$ and $418.50 \mathrm{CFU} / \mathrm{cm}^{3}$ at the respective intervals (Table 2).

The presence of mold was higher in milk without addition of the LP-s, registering values of $12.75,14.25$ and $28.50 \mathrm{CFU} / \mathrm{cm}^{3}$ at 0 -, 4 - and 8 -hours of storage, respectively. Meanwhile, with the addition of the activator of the LP-s, the presence of mold recorded values of 9.50, 10.25 and $18.00 \mathrm{CFU} / \mathrm{cm}^{3}$ at the $0-, 4$ - and 8 -hours of storage, respectively (Table 2 ). With respect to yeasts, no microorganisms were found in any of the treatments.

Neither the analysis of density nor the percentage fat provided evidence of significant differences in either of the treatments, indicating that the addition of the activator of LP-s as a preservative does not influence the physio-chemical characteristics of milk even at eight hours of storage.

\section{Discussion}

In the current study, as shown in Table 2, with respect to $\mathrm{pH}$, the results with respect to the group with the activator of the LP-s, are within of the normal limits of raw milk (between 6.6 and 6.8) [1] [14] [15], which does not occur with the results obtained in the control group, in which only initial readings indicate a normal $\mathrm{pH}$ (6.71), later diminishing significantly in the following hours, demonstrating that milk stored for some hours at ambient room temperature is susceptible to various external factors affecting the hydrogen potential [1]. This concords with studies by Galeano-López [12] in Nicaragua; although, in the aforementioned study the authors did not take as a standard reference the $\mathrm{pH}$, but rather the acidity of the milk, demonstrating that the milk that contains the LP-s conserves the acidity of the milk in normal values. acidity between 0.15 0.17 percent of lactic acid, while the milk without the activator saw the acidity gradually increase to 0.25 percent lactic acid, up from 0.18 percent; these parameters fall outside of the normal range articulated in NTE INEN 9 [3]. Other studies also have determined that the milk with the activator maintains the acidity of the milk in normal parameters (until $0.18 \%$ for 12 hours), while untreated milk exceeds this value after some hours at ambient temperature. According to Ponce [11] the LP-s inhibit the effect of proteolysis, lipolysis and the fermentation of the lactose (in lactic acid), maintaining the milk components stable for 12 hours, due to the reduction of the secretion of enzymes with said characteristics in the milk.

With respect to the presence of coliforms and total aerobes, a significant difference was observed between the treatments (a the 4 and 8 hours), signifying that the utilization of the activator of the LP-s permitted a reduction in the presence of microorganisms in milk. These data coincide with those of GaleanoLópez [12] in which the samples with the activator of the LP-s (similar to those used in this present study) show normal values in reductase, while the control 
(T0) samples show a reduced time for reduction of the methylene blue, due to bacterial multiplication. The data are also harmonious with the results obtained by Sepúlveda and Múñoz [10], who found significant differences with respect to the bacterial count between samples of milk with the activator of the LP-s (similar to that used in our study) and without which, at 12 hours of storage, since said samples presented initially low levels (0 hours), with a median of 30.000 $\mathrm{CFU} / \mathrm{ml}$ for $\mathrm{LC}$ and of $36.846 \mathrm{CFU} / \mathrm{ml}$, respectively; following 12 hours at ambient temperature (between $28^{\circ} \mathrm{C}$ and $32^{\circ} \mathrm{C}$ ), there was a higher bacterial count observed in both groups, with a median of $2.56 \times 10^{6} \mathrm{CFU} / \mathrm{ml}$ in the control (T0) and of just $0.68 \times 10^{6} \mathrm{CFU} / \mathrm{ml}$ in the samples with the activator included. Similarly, Ponce [11] demonstrated that the activation of the LP-s had in effect the count of total coliforms and of viable mesophiles, due to the bacteriostatic effect with a light reduction of bacterial load at the beginning, and increasing its bactericidal potential after 4 hours of the inoculation of the activator, arriving at its maximum expression at the 9 hours and later diminished upon reaching 12 hours. In his study, the control (T0) obtained an initial count of $6.2 \times 10^{4}$ $\mathrm{CFU} / \mathrm{ml}$, which gradually increased to $1.85 \times 10^{5} \mathrm{CFU} / \mathrm{ml}$ at the 3-hour mark, $2.3 \times 10^{6} \mathrm{CFU} / \mathrm{ml}$ at 6 hours, $2.5 \times 10^{7} \mathrm{CFU} / \mathrm{ml}$ at 9 hours and $6.2 \times 10^{7} \mathrm{CFU} / \mathrm{ml}$ at 12 hours; meanwhile, the group with the activator of the LP-s (T1) had an initial count of $5.0 \times 10^{4} \mathrm{CFU} / \mathrm{ml}$, rising to only $5.1 \times 10^{4} \mathrm{CFU} / \mathrm{ml}$ at 3 hours, $5.0 \times$ $10^{4} \mathrm{CFU} / \mathrm{ml}$ at 6 hours, $5.5 \times 10^{4} \mathrm{CFU} / \mathrm{ml}$ at 9 hours and $9.8 \times 10^{5} \mathrm{CFU} / \mathrm{ml}$ a the 12 hours. These results coincide with other investigations in which the activation of the LP-s also affects the count of total coliforms and aerobic mesophiles, which confirms the ability to conserve the quality of the milk and the combination of bactericidal and bacteriostatic effects, as much in mesophiles as it is in coliforms, demonstrated in cow milk by Spiegeleer et al. [16] and Schlorke et al [8]. Studies realized in camelid milk indicate that the response is similar after the use of activators of the LP-s, showing no difference between the different species of mammals of productive interest [17], suggesting that the activator system utilized in this trial could also be used in the milk originating from goats and sheep, species that also have roles in dairy production. This confirms that the activation of the LP-s reduces bacterial growth, showing a bacteriostatic effect, for which the milk did not acidify easily, avoiding economic losses for the producers.

With respect to the reduction of the presence Staphylococcus aureus, our data coincide with those of Kamau, Doores and Pruitt [18], who determined that the LP-s improved the thermic destruction of Listeria monocytogenes and Staphylococcus aureus, especially if the activation of the LP-s is followed by heating, raising the safety margin with respect to the pathogens transmitted by milk; it also has a significant effect on Escherichia coli $\mathrm{K} 12$ [8] and in various viruses [7]. It even demonstrated that the products of the oxidation of the thiocyanate because the lactoperoxidase inhibits gram-positive bacteria that produce peroxide, and even that they are paragram-negative bactericides (Pseudomonas and Escherichia coli), as long as the peroxide is administered exogenously.

With respect molds and yeasts our results coincide with those Popper and 
Knorr [19], their results showed with the lactoperoxidase (LPO) system with glucose oxidase (GOD) as source of hydrogen peroxide, it diminishes the initial counts of molds and yeasts, showing a clear antifungal activity.

The use of the activator of the LP-s is not detected in the quality control tests to detect the presence of preservatives and of hydrogen peroxide, realized by industry as well as official organisms, and as such is not considered an adulterant of milk [10] [11] [12] apart from being a mechanism approved by the World Health Organization [2], being convenient especially for the small-scale of the Ecuador tropics or of other parts of the world with the same geographic characteristics. The activation of the lactoperoxidase system possess a bacteriostatic activity in raw milk up until 8 hours a $30^{\circ} \mathrm{C}$ [11], raising the threshold of time for the safe transportation of milk from farmgate to market in the absence of refrigeration [12].

\section{Conclusion}

This study shows that the use of sodium thiocyanate- $0.36 \mathrm{~g} / \mathrm{liter}$ of milk-and sodium percarbonate-1.36g/liter of milk—can be an activator of the Lactoperoxidase system (LP-s) and promote the conservation of the raw milk in the Ecuadorian tropics, maintaining stable the $\mathrm{pH}$ and microbiological characteristics at ambient temperature. The utilization of the activator of the LP-s permitted in turn the financial return in its sale, offering the opportunity for small-scale producers without access to refrigeration to minimize economic losses due to discarded product along the value chain by applying this method. Also, this study indicates that the cost of conservation for each 40 liters of milk is USD \$0.25.

\section{Acknowledgements}

To the Universidad Estatal de Quevedo and to Ing. Cristian Vallejo for all of the facilities provided in the course of this study.

\section{References}

[1] López, A. (2003) Manual de Industrias Lácteas. In: Madrid Vicente, E.A., Ed., Primera, Madrid.

[2] FAO-OMS (2005) Lactoperoxidasa. http://www.fao.org/food/food-safety-quality/a-z-index/lactoperoxidase/es/

[3] INEN. (2015) Leche Cruda: Requisitos. Quito-Ecuador. http://www.normalizacion.gob.ec/wp-content/uploads/downloads/2015/07/nte_ine n_009_6r.pdf

[4] Molina, F. (2009) Determinación de la calidad de leche cruda (acidez, densidad, grasa, reductasa, sólidos totales), aplicando un programa de capacitación en 4 comunidades de la parroquia Pintag, Cantón Quito. Escuela Superior Politécnica de Chimborazo.

http://studylib.es/doc/8364415/determinaci\%C3\%B3n---dspace-espoch.---escuela-s uperior-polit\%C3\%A9c

[5] Bafort, F., Parisi, O., Perraudin, J. and Jijakli, M. (2014) Mode of Action of Lactoperoxidase as Related to Its Antimicrobial Activity: A Review. Enzyme Research, 
2014, Article ID: 517164. https://doi.org/10.1155/2014/517164

[6] Prashant, K., Singh, H.V, Sirohi, N.I., Pragya, T., Punit, K. and Sujata, S. (2017) Structure of Bovine Lactoperoxidase with a Partially Linked Heme Moiety at $1.98 \AA$ Resolution. Biochimica et Biophysica Acta (BBA)-Proteins and Proteomics, 1865, 329-335.

[7] El-Fakharany, E., Uversky, V. and Redwan, E. (2016) Comparative Analysis of the Antiviral Activity of Camel, Bovine, and Human Lactoperoxidases Against Herpes Simplex Virus Type 1. Applied Biochemistry and Biotechnology, 182, 294-310.

[8] Schlorke, D., Atosuo, J., Flemmig, J., Lilius, E. and Arnhold, J. (2016) Impact of Cyanogen Iodide in Killing of Escherichia coli by the Lactoperoxidase-Hydrogen Peroxide-(Pseudo)Halide System. Free Radical Research, 50, 1287-1295. https://doi.org/10.1080/10715762.2016.1235789

[9] Yong, L., Wang, Y., Yang, D. and Li, J. (2017) Investigation of Concentration of Thiocyanate Ion in Raw Cow's Milk from China, New Zealand and the Netherlands. Food Chemistry, 215, 61-66.

[10] Sepúlveda, N., Muñoz, A. and Jara, R. (2003) Evaluación de un activador del sistema lactoperoxidasa en leche sin refrigerar recolectada de pequeños productores. Evaluation of an of Lacto-Peroxidase System Activator in Milk without Refrigeration on Small Dairy Farms. Revista Científica, XIII, 12-17.

[11] Ponce, P. (2007) Activación del sistema lactoperoxidasa para la conservación de leche cruda en el trópico americano. Aspectos prácticos y consideraciones toxicológicas. San José de las Lajas, La Habana-Cuba.

[12] Galeano López, B. (2012) Efecto del sistema lactoperoxidasa en la conservación de la leche cruda en dos fincas de la comunidad Monte Rosa, El Rama-RAAS, Nicaragua. Universidad Nacional Agraria de Nicaragua. http://repositorio.una.edu.ni/1456/

[13] INEN, I. N. de N. (2008) Leche y productos lácteos: muestreo. Quito-Ecuador. http://www.normalizacion.gob.ec/wp-content/uploads/downloads/2013/11/rte_4_4. pdf

[14] Alviar, J. (2010) Manual Agropecuario. Técnicas orgánicas de la granja integral autosuficiente. (Editorial Limerin, Ed.) (Segunda). Bogotá-Colombia.

[15] Carrión, A. (2008) Influencia de los diferentes grados de mastitis sobre el porcentaje de materia grasa, densidad, acidez, ph y reductasa de leche receptada en lácteos San Antonio. Escuela Superior Politécnica de Chimborazo. Riobamba-Ecuador. http://dspace.espoch.edu.ec/handle/123456789/1512

[16] De Spiegeleer, P., Vanoirbeek, K., Lietaert, A., Sermon, J., Aertsen, A. and Michiels, C. (2005) Investigation into the Resistance of Lactoperoxidase Tolerant Escherichia coli Mutants to Different Forms of Oxidative Stress. FEMS Microbiology Letters, 252, 315-319. https://doi.org/10.1016/j.femsle.2005.09.010

[17] Ramet, J. and Soukehal, A.-H. (2003) Conservation du Lait cru de Chamelle par Reactivation du Systeme Lactoperoxidase et Fabrication de fromages Camelins. Camelides Cirad. http://camelides.cirad.fr/fr/actualites/archives/synth_niamey.html

[18] Kamau, D.N., Doores, S. and Pruitt, K.M. (1990) Antibacterial Activity of the Lactoperoxidase System against Listeria monocytogenes and Staphylococcus aureus in Milk. Journal of Food Protection, 53, 1010-1014. https://doi.org/10.4315/0362-028X-53.12.1010

[19] Popper, L. and Knorr, D (1997) Inactivation of Yeast and Filamentous Fungi by the Lactoperoxidase-Hydrogen Peroxide-Thiocyanate-System. Molecular Nutrition \& Food Research, 41, 29-33. https://doi.org/10.1002/food.19970410108 
Submit or recommend next manuscript to SCIRP and we will provide best service for you:

Accepting pre-submission inquiries through Email, Facebook, LinkedIn, Twitter, etc. A wide selection of journals (inclusive of 9 subjects, more than 200 journals)

Providing 24-hour high-quality service

User-friendly online submission system

Fair and swift peer-review system

Efficient typesetting and proofreading procedure

Display of the result of downloads and visits, as well as the number of cited articles Maximum dissemination of your research work

Submit your manuscript at: http://papersubmission.scirp.org/

Or contact fns@scirp.org 